\title{
Zirconium Zr 89 Bevacizumab
}

National Cancer Institute

\section{Source}

National Cancer Institute. Zirconium Zr 89 Bevacizumab. NCI Thesaurus. Code C82656.

A radioimmunoconjug ate comprised of the recombinant humanized monoclonal antibody bevacizumab labeled with the radioisotope zirconium Zr 89 (Zr 89) with radioisotopic activity and potential imaging use. The antibody moiety of zirconium $\mathrm{Zr} 89$ bevacizumab targets and binds to the extracellular domain of the vascular endothelial growth factor receptor (VEGFR). Upon binding, the radioisotope moiety may be detected using positron emission tomography (PET), allowing the imaging and quantification of VEGFR-expressing tumor cells. VEGFR, a tyrosine kinase, is overexpressed on the cell surfaces of various tumor cell types. 